\title{
The Effect of Intellectual Capital Measurement on Profitability and Market Price
}

\author{
Dian Prawitasari \\ Faculty of Economic and Business \\ University of Dian Nuswantoro \\ Semarang, Indonesia \\ Sari.dianprawita@yahoo.co.id
}

\author{
Ririh Dian Pratiwi \\ Faculty of Economic and Business \\ University of Dian Nuswantoro \\ Semarang, Indonesia \\ ririh.dian.pratiwi@dsn.dinus.ac.id
}

\author{
Nila Tristiarini \\ Faculty of Economic and Business \\ University of Dian Nuswantoro \\ Semarang, Indonesia \\ nila.tristiarini@dsn.dinus.ac.id
}

\begin{abstract}
Recently, the role of Intellectual Capital is becoming one of the important strategies of the company to develop and grow, enhance it is able to improve the company's value with the utilization of existing resources Intellectual capital is the knowledge that gives information about the company's intangible value, which can affect durability and contribute to the company's competitive advantage. This research aims to analyze the intellectual capital measurement, which is able to increase profitability and market price. The research variable consists of Value Added Capital Employed, Value Added Human Capital, and Structural Capital Value Added as the independent variables, and profitability as well as Market price as the dependent variable. The population of this research is the banking company listed on the Indonesia stock exchange over the period 2014-2016. The sampling technique using purposive sampling method and using samples of 36 banking companies. The data analysis tools using WarpPLS 3.0. The result shows that only Value Added Capital Employed affects on the profitability and market price.
\end{abstract}

\section{Keywords - Intelectual Capital. Profitability, Market Price}

\section{INTRODUCTION}

An experienced company excels with the development of a good market. From the internal side, the condition will improve the profitability of the company. Profitability is an ability owned by the company in generating profits. The company's internal condition is getting better demand for investors, so as the demand for stocks grow, it will have an impact on the company's increase.

According to the theory of the firm firm is usually established with the main purpose of maximizing its value (Salvatore, 2005). According to Husnan (1997), corporate value is defined as a condition of company achievement in terms of public trust to the company. Thus, the value of the firm is the price paid by the prospective buyer if the company is sold. In this case, the value of a company is also reflected in the value of assets owned in the form of corporate securities, one of which is the stock. In conjunction with shareholders, with higher stock market prices it will provide increasing prosperity to shareholders (Bringham Gapensi, 1996). The difference between the value of the firm from the external side reflected in the market value and the company's value from the internal side of the company reflected in profitability has attracted researchers to conduct research on the existence of the hidden value (Hidden value) in the company's financial statements, namely the form of hidden assets owned companies that can increase the value of the company. Hidden value of a company indicates the existence of information about intangible assets, for example human capital, innovation and technology or customers that are usually not included by the management into the financial statements. This is because of difficulties in the process of identification and measurement.

The intangible assets discussed in this regard are intellectual capital which refers to non-physical capital related to human knowledge or experience or technology used by the firm (Chen et al., 2005). Intellectual capital or intellectual capital is believed to play an important role in increasing the value of the company. Companies that are able to use intellectual capital efficiently, then the value of the company will increase both the value of the company from the internal and external. According to Sawarjuwono and Kadir (2003), the company has changed the way of doing business from labor based business to knowledge based business (knowledge based business). The hope is that companies that do business based on knowledge will be able to use their knowledge to increase their profits in order to sustain their business in the future by developing the company's intangible assets. Such intangible assets can be measured and assessed with intellectual capital (Guthrie, 2000).

Studies and discussions on intellectual capital have evolved since the 1990s. After PSAK No. 19 discussing intangible assets arises, many companies in Indonesia are exploiting the intangible assets they have, in this case intellectual capital to grow their business. Under PSAK 19 (2015), intangible assets are non-monetary assets that can be identified without physical form. Meanwhile, according to Ulum (2009), intellectual capital is the difference between the market value of a company with the value of his book. Intellectual capital has three main components, namely human capital, structural capital, and customer capital.

Intellectual capital can be measured by several models. According to Pulic (1998), intellectual capital can be measured using VAIC (Value Added Intellectual Coefficient) model with the main components of company's resources in the form of physical capital (VACA - Value Added Capital Employed), human capital (VAHU - Value Added Human 
Capital), and structural capital (STVA- Structural Capital Value Added). These components aim to provide added value for a company in an effort to know the size of the physical capital owned which consists of financial funds and intellectual potential in the form of value given to employees for their ability and contribution.

\section{LITERATURE REVIEW}

\section{A. Resources based theory}

According to Newbert (2007) Resources based theory is a widely accepted theory, where the theory is resource-based, develops in the strategic management of a company. Resources Based Theory states that the company has resources that can make itself a competitive advantage and strive to have a good performance in the long run (Ulum, 2015). According to Susanto (2007) Resources Based Theory determines the resources as a key potential for the company in achieving sustainable competitive advantage so that the identification process of various types of corporate resources needs to be done first.

Resources owned by a company are classified into three, namely tangible, intangible, and human resources. Tangible resources owned by a company are usually physical assets, while trademarks are one example of an intangible resource. According to Pramelasari (2010) the three resources owned by the company is very instrumental in producing sustainable corporate advantage. Nevertheless, the role of these resources varies, so companies must be selective in determining their key resources.

There are several criteria when a firm wants to determine its key resources, which include: (a) the ability of those resources to support a company to better meet customer needs than a competing company, (b) such resources are scarce, making it difficult to replicate and available in limited quantities or, (c) resources must be profitable for the enterprise, (d) resources must have high endurance, the slower the resource is depreciated the higher and more valuable the resource.

The importance of the management of intellectual capital owned by a company by utilizing the intellectual capital maximally must be realized by the company. So that management can create a value that can provide a good characteristic for the company. With the existence of its own characteristics owned by the company, is expected to improve competitiveness with competitors.

\section{B. Stakeholder Theory}

According to Ghozali and Chariri (2007), stakeholder theory is a theory that describes that as an entity, a company must be able to benefit all stakeholders, ie shareholders, suppliers, governments, creditors, consumers, and others. The main purpose of this theory is for management to improve the creation of a quality value of all activities undertaken, as well as minimize possible losses.

According to Deegan (2000), this theory states that all stakeholders have the right to obtain all information about all activities of the company that will affect them. In general, this theory aims to reduce the responsibility of managers of a company in overcoming the impact that will be generated from the activities of the company. Tools that can be used to communicate between managers and the company's stakeholders are financial statements.

In addition to providing fair information, a company is also obliged to treat equally the stakeholders by managing the company well in order to benefit all stakeholders. In this case, management must be able to manage all the resources of the company, whether in the form of employees or physical assets. Thus, a company that can manage and utilize well, all its resources will create value added (value added) for the company, so the financial performance of the company will also increase.

\section{Intellectual Capital}

According to Stewart (1997), intellectual capital is everything that is in the company to be used as a support for competing in the market, which includes intellectual material, information, knowledge, experience, and intellectual property that can be used to create corporate welfare. Intellectual capital is also an intangible asset that includes information and knowledge, which plays a very important role as it indicates the capabilities possessed by a particular organization.

The model in measuring intellectual capital developed by Pulic (1998) is Value Added Intellectual Coefficient (VAIC). VAIC has three main components: physical capital (VACA Value Added Capital Employed), human capital (VAHU Value Added Human Capital), and structural capital (STVA Structural Capital Value Added). According to Ulum (2015), VACA is an inner formula that measures the utilization of physical capital held by the organization, VAHU is a formula that measures the utilization of human resources. While STVA is a formula that measures the structural capital management.

\section{Profitability}

The measure used to measure company performance is the profitability ratio, which describes the company's ability to generate profits. According to Brigham and Houston (2001), profitability ratios are a group of ratios that explain the effects of liquidation, assets, management, and debt on the results of operations. Referring to an assumption that intellectual capital is a very important resource held by a company to maintain its competitive advantage (Pulic and Kolakovic, 2003), the performance of the company's intellectual capital is believed to have an influence on its financial performance.

\section{E. Market Price}

According to Anoraga (2001), the share price is merupakaan money to obtain evidence of ownership of a company. In other cases, the price of a bond can also be interpreted as the price formed from transacons by the seller and the buyer, each of which has a purpose for profit. For these purposes, investors usually (buyers of shares) need the 
information necessary in making decisions to invest, specifically the decision to sell or buy shares.

\section{RESEARCH METHOD}

Population in the observation period 2014-2016 is a banking company listed on the Indonesia Stock Exchange. Then according to sample selection criteria by using purposive sampling method then obtained 36 banking companies.

Exogenous variable in this research is Value Added Intellectual Coefficient (VAIC). VAIC has three main components: physical capital (VACA - Value Added Capital Employed), human capital (VAHU), and structural capital (STVA - Structural Capital Value Added). In this study VAIC is calculated as follow:

$$
\begin{aligned}
& \mathrm{VACA}=\frac{\mathrm{VA}}{\mathrm{CE}} \\
& \mathrm{VACU}=\frac{\mathrm{VA}}{\mathrm{HC}} \\
& \mathrm{STVA}=\mathrm{VA}-\mathrm{HC}
\end{aligned}
$$

Where :

$$
\begin{aligned}
\mathrm{VA}= & \text { Output }- \text { Input } \\
\text { Output }= & \text { Net Sales and others income } \\
\text { Input = } & \text { Expenses (other than personnel expenses) } \\
& \text { HC = Employee expense is the amount of } \\
& \text { salary and employee expenses stated in the } \\
& \text { financial statements } \\
\mathrm{CE} \quad & \text { Capital Employed }: \text { Total Equity }
\end{aligned}
$$

Endogenous variables in this study are Profitability and Market Price. Profitability is a description of financial performance in this study measured by using Earning Per Share (EPS) can be measured by the following formula :

$\mathrm{EPS}=$ Earning after Tax

$$
\text { Total Outstanding Stock }
$$

Market price is used to measure how much the company is valued by investors. In this study measured by using the stock price can be measured by the formula as folow:

\section{Stock Price $=$ Closing Price}

This research uses Structural Equation Modeling (SEM) analysis tool with WarpPLS version 3.00 program used to test hypothesis. (Latan and Ghozali, 2012). The research

\begin{tabular}{|c|c|c|c|c|c|}
\hline $\begin{array}{c}\text { Var } \\
\text { iabel }\end{array}$ & & $\mathrm{n}^{\mathrm{Mi}}$ & Max & $\begin{array}{c}M \\
\text { ean }\end{array}$ & $\begin{array}{l}\text { Stand } \\
\text { Dev }\end{array}$ \\
\hline VA & & 0.0 & 0.44 & 0.2 & 0.098 \\
\hline CA & 6 & 410 & 13 & 291 & 2 \\
\hline VA & & 0.9 & 8.66 & 2.6 & 1.392 \\
\hline HU & 6 & 165 & 25 & 852 & 4 \\
\hline STV & & - & 0.88 & 0.5 & 0.193 \\
\hline A & 6 & 0.0911 & 46 & 530 & 4 \\
\hline & & - & 1,06 & 28 & \\
\hline EPS & 6 & 493 & 2 & 1 & 364 \\
\hline & & & 15,5 & 4,2 & \\
\hline SP & 6 & 96 & 00 & 37 & 4,856 \\
\hline
\end{tabular}
framework can be illustrated using the analytical path in figure 1:

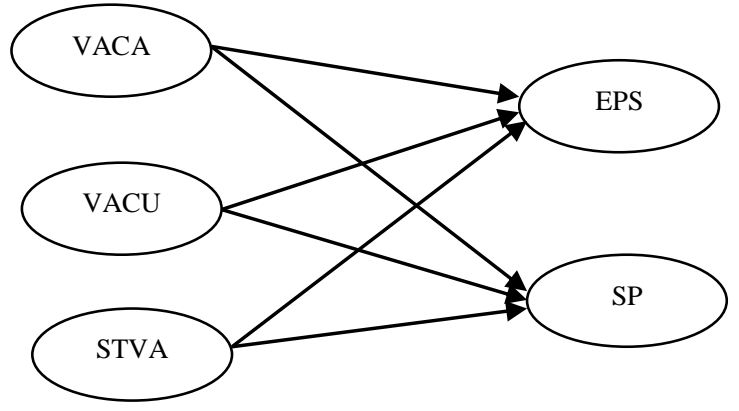

Figure 1. Conceptual Research Framework

\section{RESULT}

\subsection{Descriptive Statistics}

Descriptive statistics are used to explain the characteristics of research variables used. Therefore explanation of descriptive statistics of research variables are as follows :

Table 1. Descriptive Statistics of Research Variables

Source : Processed data used in this study; VACA = Value Added Capital Employed; VAHU = Value Added Human Capital $;$ STVA = Structural Capital Value Added; EPS = Earning Per Share; SP = Stock Price

From table 1 the descriptive statistics of the research variables show that the VACA variable has an average of 0.2291 with a standard deviation of 0.0982 . The average value for VAHU is 2.6852, with a standard deviation of 1.3924 . While the average value of STVA of 0.5530 with standard deviation of 0.1934 and for the average value for EPS of 281, with a standard deviation of 364 and for the average SP value of 4.237 with a standard deviation of 4.856 .

\subsection{Hypothesis Testing}

\subsubsection{Path Analysis}

To be able to answer the hypothesis then made path analysis that describes the causality relationship between exogenous variables ie VACA, VAHU and STVA with endogenous variables ie EPS and SP. So after doing run-test obtained path analysis in Figure 2: 


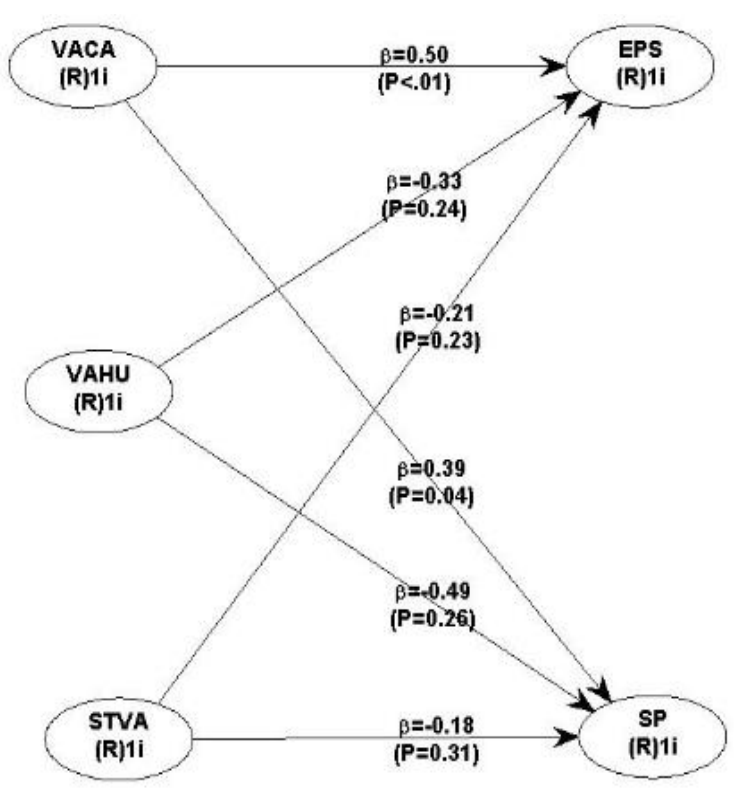

Figure 2. Path Analysis

Source : Processed data used in this study

From Figure 2 above, showing the causality relationship between exogenous variables with endogenous variables, then from the path analysis can be seen the results of Path coefficients and $\mathrm{P}$ value test to see the magnitude of coefficient and significance level in Table 2:

Table 2. Path coefficients and $P$ value Result

\begin{tabular}{|c|r|r|}
\hline \multirow{2}{*}{ Path } & \multicolumn{2}{|c|}{ Dirrect Effect } \\
\cline { 2 - 3 } & Koefisien & P-Value \\
\hline VACA $\rightarrow$ EPS & 0.50 & $<0.01^{*}$ \\
\hline VAHU $\rightarrow$ EPS & -0.33 & 0.24 \\
\hline STVA $\rightarrow$ EPS & -0.21 & 0.23 \\
\hline VACA $\rightarrow$ SP & 0.39 & $0.04^{*}$ \\
\hline VAHU $\rightarrow$ SP & -0.49 & 0.29 \\
\hline STVA $\rightarrow$ SP & -0.18 & 0.31 \\
\hline
\end{tabular}

Source : Processed data used in this study; VACA = Value Added Capital Employed; VAHU = Value Added Human Capital $;$ STVA = Structural Capital Value Added; EPS = Earning Per Share; $\mathrm{SP}=$ Stock Price

* Significance level 5\%

From Table 2 shows the test results that the direct effect coefficient of VACA on EPS is 0.50 and significant at $p<0.01$. Then it can be concluded that the first hypothesis (H1) accepted that the VACA has a significant effect on EPS. The direct effect coefficient of VAHU to EPS is -0.33 and significant at 0.24 . Then it can be concluded that the second hypothesis (H2) is rejected that VAHU has no effect on EPS. The direct effect coefficient of STVA to EPS is -0.21 and significant at 0.23 . So it can be concluded that the third hypothesis (H3) is rejected that the STVA has no effect on EPS.

The coefficient of direct effect of VACA on SP is 0.39 and significant at 0.04 . Then it can be concluded that the fourth hypothesis (H4) accepted that the VACA has a significant effect on SP. The coefficient of direct effect of VAHU to SP is equal to -0.49 and significant at 0.29 . It can be concluded that the fifth hypothesis (H5) is rejected that the VAHU has no effect on SP. The direct effect coefficient of STVA to SP is equal to -0.18 and significant at 0.31 . Then it can be concluded that the sixth hypothesis (H6) is rejected that the STVA has no effect on SP.

\section{CONCLUSION AND IMPLICATION}

The result of research shows that from the three main components of intellectual capital developed by Pulic (1998), Value Added Intellectual Coefficient, which has a direct influence on the improvement of company's financial performance (Earning Per Share and Stock Price) is Value Added Capital Employed which measure the utilization of physical capital owned by the organization. While other components of Value Added Human Capital and Structural Capital Value Added have no effect on financial performance. Then it can be concluded that the intellectual capital measured using Capital Employed has more dominant influence than other components in improving financial performance.

From the conclusion above, it is hoped that this research has implication to company strategy in making decision to maximize Value Added Capital Employed because it has direct influence in improving financial performance, so it is expected to contribute in the development of science, especially in Accounting.

\section{REFERENCES}

[1] "Pernyataan Standar Akuntansi Keuangan No.19", Salemba Empat. Jakarta, 2015.

[2] A. Kadir, "Pengenalan Sistem Informasi", Andi. Yogyakarta, 2003.

[3] A. Pulic, "Value Creation Efficiency in The New Economy," Global Business and Economic Review, Vol. 5, No. 1, pp. 111-128, 2003.

[4] A..B. Susanto, "Corporate Social Responsibility", The Jakarta Consulting Goroup. Jakarta, 2007.

[5] C. Deegan, "Financial Accounting Theory", McGrawHill. Australia NSW, 2000.

[6] Chen et al, "An Empirical Investigation of The Relationship Between Intelectual Capital and Firm's Market Value and Financial Performance", Journal of Intelectual capital, Vol. 6, No.2, pp 159-176, 2005.

[7] D. Salvator, "Managerial Economics," Salemba Empat. Jakarta, $5^{\text {th }}$ ed., 2012.

[8] E.F. Bringham and L.C. Gapensi, "Intermediate Finance Management," J.Harbour Drive, The Dryden Press, $15^{\text {th }}$ ed, 1996.

[9] I. Ghozali and A. Chariri, "Teori Akuntansi”, Andi. Yogyakarta, 2007.

[10] I. Ulum, "Intellectual Capital : Model Pengukuran, Framework Pengungkapan, dan Kinerja Organisasi”, Universitas Muhammadiyah Malang Press. Malang, 2015

[11] I. Ulum, "Intellectual Capital: Konsep dan Kajian Empiris", Graha Ilmu. Yogyakarta, 2009. 
[12] J. Gutri, "Intellectual Capital Literature Review: Measurement, Reporting and Management," Journal of Intellectual Capital, Vol.1 No. 2, pp.160-176, 2000.

[13] J. Gutri, "Intellectual Capital Literature Review: Measurement, Reporting and Management," Journal of Intellectual Capital, Vol.1 No. 2, pp.160-176, 2000.

[14] S. Husnan, "Manajemen Keuangan Teori dan Penerapan (Keputusan Jangka Panjang", BPFE. Yogyakarta, 1997.
[15] S.L. Newbert, "Empirical Research on The Resource-Based View of The Firm: An Assesment adan Suggestions fo Future Reseach", Strategic Managemen Journal, 28, pp. 121-146, 2007.

[16] T.A. Stewart, "Intelectual Capital : The New Wealt of Organization", Doubleday. Newyork, 1997. 